\title{
The Influence of Human Resources and Infrastructure on Service Process and Service Quality
}

\author{
Awaluddin Sam, Gunawan, Buyung Ramadhoni \\ Sekolah Tinggi Ilmu Ekonomi AMKOP Makassar, Indonesia \\ awaluddinsam@gmail.com,gunawan@gmail.com, buyungramadhoni@gmail.com \\ Hasanuddin \\ Universitas Muhammadiyah Bone, Indonesia \\ hasanuddin77@gmail.com \\ Yusriadi Yusriadi \\ Sekolah Tinggi Ilmu Administrasi Puangrimaggalatung, Makassar, Indonesia \\ yusriadi.yusriadi@uqconnect.edu.au \\ Suherman \\ STIAB Smaratungga \\ herusuhermanlim@gmail.com \\ Muhammad Nurjaya \\ Economic and Bisnis Faculty, Moslem Maros University, Indonesia \\ nurjaya@umma.ac.id
}

\begin{abstract}
This study analyzes human resources and infrastructure on the service process and service quality at Class IIA Correctional Institutions in Gowa Regency. The research design and approach used is an explanatory approach with quantitative methods. The research method used is Path Analysis, for the sample in this study were all employees totaling 116 employees. The results showed that: 1) Human resources had a positive and significant effect on the service process; 2) facilities have a positive and significant impact on the service process; 3) Human resources have a positive and significant impact on service quality: 4) Infrastructure facilities have a positive and significant effect on service quality; 5) The service process has a positive and significant impact on service quality; 6) Human resources have a positive and significant impact on service processes and service quality; 7) Infrastructure has a positive and significant effect on service processes and service quality.
\end{abstract}

\section{Keywords:}

Human Resources, Infrastructure, Process, Quality, Service

\section{Biographies}

Awaluddin Sam is a student at Magister Program of Economic Science of STIE AMKOP, Indonesia. His areas of interest and research include social science and economic. He has published some articles in national journals.

Gunawan is a lecturer at Economics Department of STIE AMKOP, Indonesia. His areas of interest and research include economic, management, management human resource. He has published some books and many articles in national and international journals. 
Buyung Ramadhoni is a lecturer at the Management Department, Faculty of Business, and Economics, STIE AMKOP, Makassar. She has published some books and many articles in national and international journals. She is also a reviewer and editor in some local and international journals.

Hasanuddinis a lecturer at civic education Department of Univeritas Muhammadiyah Bone, Indonesia. His areas of interest and research include economic, management, management human resource. He has published some books and many articles in national and international journals.

Yusriadi Yusriadi is a lecturer at Public Administration Department of Sekolah Tinggi Ilmu Administrasi Puangrimaggalatung, Indonesia and chancellor on Sekolah Tinggi Ilmu Hukum Pengayoman. His areas of interest and research include social science, political science, sociology, legal studies, and public administration. He has published some books and many articles in national and international journals. He is a reviewer and editor in some local and international journals.

Suherman Head of PostGraduate at STIAB Smaratungga, Boyolali, Central Java. He completed his bachelor degree in Information Technologies from Universitas Bina Nusantara - Jakarta (UBinus) and received his postgraduate from Marketing Management from Universitas Pelita Harapan - Jakarta (UPH), and he has take doctoral from UPI (Universitas Pendidikan Indonesia) in Education Administration.

Muhammad Nurjaya is an Associate Professor, in Economic and Bisnis Faculty, Moslem Maros University, Indonesia Since 2010, he teaches courses in Organization Behavior, Leadhershif, Corruption, Decision making 